THINKING LIKE A CLIMATE 
This page intentionally left blank 
HANNAH KNOX

\section{THINKING LIKE A CLIMATE}

Governing a City in Times of Environmental Change 
(C) 2020 Duke University Press

All rights reserved

Printed in the United States of America on acid-free paper $\infty$ Designed by Matthew Tauch

Typeset in Arno Pro and TheSans C4s by Copperline Books

Library of Congress Cataloging-in-Publication Data

Names: Knox, Hannah, [date] author.

Title: Thinking like a climate : governing a city in times

of environmental change / Hannah Knox.

Description: Durham : Duke University Press, 2020.|

Includes bibliographical references and index.

Identifiers: LCCN 2020006170 (print)

LCCN 2020006171 (ebook)

ISBN 9781478009818 (hardcover)

ISBN 9781478010869 (paperback)

ISBN 9781478012405 (ebook)

Subjects: LCSH: Climatic changes-Government

policy_England-Manchester. | Climatic changes-

Research-England-Manchester.

Classification: LCC QC903.2.G7 K569 2020 (print)

LCC QC903.2.G7 (ebook)

DDC $363.738 / 745610942733$ - d c23

LC record available at https://lccn.loc.gov/2020006170

LC ebook record available at https://lccn.loc.gov/2020006171

Cover art: Jesús Perea, Abstract composition 593.

Courtesy of the artist. 
A lost number in the equation, A simple, understandable miscalculation. And what if on the basis of that The world as we know it changed its matter of fact? Let me get it right. What if we got it wrong? What if we weakened ourselves getting strong? What if we found in the ground a vial of proof? What if the foundations missed a vital truth? What if the industrial dream sold us out from within? What if our impenetrable defence sealed us in? What if our wanting more was making less? And what if all of this ... it wasn't progress? Let me get it right. What if we got it wrong? — EXCERPt fROM leMN Sissay, "What if?" 
This page intentionally left blank 